\title{
MUSIK SEBAGAI MEDIA DAKWAH DALAM PEMBERDAYAAN SISWA TUNA GRAHITA NIPOTOWE PALU
}

\author{
Mohammad Nawir \\ Mokh Ulil Hidayat \\ Iskandar Iskandar \\ Institut Agama Islam Negeri Palu \\ Email: mokhdayat@gmail.com
}

\begin{abstract}
:
This paper deals with the use of music as media of preaching in empowering the students of Tuna Grahita Nipotowe Palu. The question are what kind of music is it? How to use music as media of preaching? The result showed that music as media of preaching has great benefits for the students. The benefits include making them comfortable, motivated, cheerful, and happy. Music makes them active in every activities given by the instructor. Music also improves their memories and influences their psychology. Furthermore, music helps to empower the students, makes them have effective communication, and can be made as therapy for the students.

$$
\begin{aligned}
& \text { تتناول هذا البحث على استخدام الموسيقى كوسائل الدعوة في تمكين الطلاب من مدرسة } \\
& \text { Tunagrahita Nipotowe }
\end{aligned}
$$

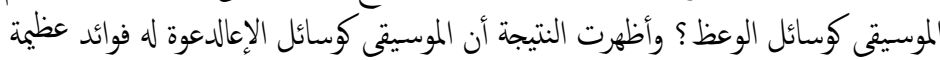

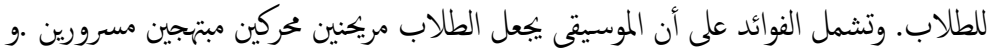

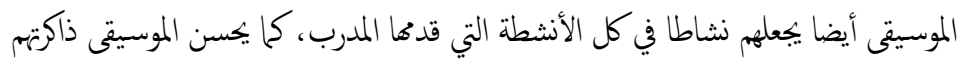

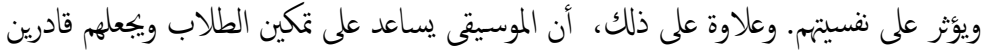

$$
\begin{aligned}
& \text { على التواصل الفعال، ويكن أن يكون علاجا للطلاب. }
\end{aligned}
$$

Kata Kunci: musik, media, dakwah, pemberdayaan, tunagrahita. 
Mohammad Nawir, Mokh. Ulil Hidayat, Iskandar, Musik Sebagai...

\section{A. Pendahuluan}

Salah satu ajaran Islam (khususnya tasawuf) yang paling penting adalah penyucian jiwa. Penyucian jiwa itu ada kalanya dilakukan dengan al-samā' $u$ (mendengar), yaitu mendengarkan musik yang indah sebagai alat purifikasi (penyucian/pembersih jiwa). ${ }^{1}$ Dengan demikian, musik adalah sarana penyucian jiwa dan pengenalan unsur rohani dari diri seseorang. Musik tidak hanya menyentuh, tetapi meresap dan merasuk jiwa dan hati pendengarnya. Jiwa manusia akan terangkat tinggi menjulang ke alam ruhani ketika ia mendengar melodi indah. ${ }^{2}$

Musik merupakan kesenian yang keindahannya dapat dinikmati melalui indera pendengaran dan telah ada sejak zaman sebelum datangnya Islam. Di Arab, musik dinikmati dengan berbagai macam cara, sesuai dengan suasana hati para penikmatnya. Tetapi pada saat itu, mayoritas musik digunakan untuk bersenang-senang dan hura-hura. Di tempat pertunjukan musik, mereka menari-nari dalam keadaan mabuk menikmati lagu-lagu yang dilantunkan oleh para pemusik yang kesemuanya adalah wanita hamba sahaya. Tidak ada pemusik laki-laki atau orang merdeka, karena bagi mereka menjadi pemusik dianggap sebagai aib bagi orang merdeka dan kaum laki-laki. ${ }^{3}$

Dalam sejarah peradaban manusia, belum ditemukan suatu kaum yang meninggalkan musik. ${ }^{4}$ Musik berkembang sejalan dengan

${ }^{1}$ Abdul Muhaya, Bersufi Melalui Musik, Sebuah Pembelaan Musik Sufi Oleh Ahmad Al-Gazāli, (Yogyakarta: Gama Media, 2003), h. 2

${ }^{2}$ Alwi Shihab, Islam Inklusif, (Bandung: Mizan, 1999), h. 234

${ }^{3}$ Yusuf Al-Qardhawy, Nasyid Versus Musik Jahiliyah, terj. H. Ahmad Fulex Bisri, H. Awan Sumarna, H Anwar Mustafa, (Bandung: Mujahid Press, 2003), h. 9-10

${ }^{4}$ Ibid. 
perkembangan zaman dan peradaban manusia. Musik adalah perilaku sosial yang kompleks dan universal. Musik dimiliki oleh setiap masyarakat, dan setiap anggota masyarakat adalah "musikal". 5

Perjalanan sejarah kebudayaan Islam mengantarkan perkembangan musik ke arah musik yang bercorak Islam. Perkembangan musik dalam budaya Islam sendiri juga beragam. Ada musik yang disebut Musik Sufi, ada musik yang biasa ditampilkan untuk hadirin di sebuah pengajian atau majelis ta ' $\hbar m$, ada juga musik "Islami" yang menembus dunia industri, seperti kelompok nasyid Snada, Raihan dan lain-lain. ${ }^{6}$

Dari deskripsi singkat di atas, dapat disimpulkan bahwa musik dapat digunakan manusia untuk berbagai macam tujuan. Dari tujuan untuk mendekatkan manusia kepada Tuhan, sekedar hiburan, untuk mencari uang, bahkan ada juga orang menggunakan musik untuk pemenuhan hawa nafsu yang menyebabkan manusia lupa akan dirinya sebagai makhluk Tuhan. Dan pada penelitian ini penulis akan membahas peran musik dijadikan sebagai salah satu pendekatan bimbingan konseling Islam dalam pemberdayaan siswa.

Dimana kita ketahui bahwa bimbingan dan konseling Islam merupakan salah satu komponen dari pendidikan. Jadi dapat diartikan bahwabimbingan dan konseling Islam adalah usaha memberikan bantuan kepada seseorang atau sekelompok orang yang sedang mengalami kesulitan lahir dan batin menjalankan tugas-tugas hidupnya dengan menggunakan pendekatan agama, yakni dengan

${ }^{5}$ Djohan, Psikologi Musik, (Yogyakarta: Buku Baik, 2003), h. 7-8

${ }^{6}$ Abdul Muhaya, Bersufi... h. 12 
Mohammad Nawir, Mokh. Ulil Hidayat, Iskandar, Musik Sebagai...

membangkitkan kekuatan getaran batin (Iman) didalam dirinya untuk mendorongnya mengatasi masalah yang dihadapi. ${ }^{7}$

Perlu kita ketahui bahwa Tunagrahita merupakan sebuah istilah yang digunakan untuk menyebut siswa yang mempunyai kemampuan intelektual dibawa rata-rata atau dikenal juga dengan istilah keterbelakangan mental karena keterbatasan kecerdasanya mengakibatkan dirinya sukar untuk mengikuti program pendidikan disekolah biasa secara klasikal, oleh karena itu anak terbelakang mental membutuhkan layanan pendidikan secara khusus yakni disesuaikan dengan kemampuan anak tersebut.

Oleh karena itu, melihat berbagai hal tersebut di atas, memperjelas gambaran bahwa memang selayaknya musik yang dijadikan sebagai media dakwah harus dimaksimalkan guna membantu dan mempermudah siswa Tunagrahita dalam meningkatkan mutu pendidikan dengan keterbatasan yang mereka miliki.

\section{B. Konsep Musik}

\section{Pengertian Musik Secara Umum}

Musik dalam bahasa Yunani diambil dari kata muse yang memiliki makna dewa. Pengertian musik dalam Kamus Ilmiah Populer dapat dikatakan sebagai panduan bunyi dari beberapa alat atau instrumen musik yang bernada secara teratur dan berkesesuaian atau seni susun padu nada. ${ }^{8}$

\section{h. $4-5$.}

${ }^{7}$ Ahmad Mubarok, Teori dan Kasus, (cet, I; Jakarta: Bina Rena Pariwara, 2000),

${ }^{8}$ M. Dahlan Yakub Al Barry, Kamus Ilmiah Populer, (Surabaya: Penerbit Arkola, 1994), h. 501. 
Budilinggono dalam pandangannya, mengatakan bahwa "musik adalah perwujudan ide-ide atau emosi-emosi yang tidak hanya tersusun atas nada, ritme, tempo, dinamik, warna suara, dan unsur-unsur lainnya." Adanya musik itu sendiri pada akhirnya memiliki suatu makna. Sehingga musik dapat diketahui dari suatu paduan suara atau juga yang terdiri dari susunan nada yang diatur oleh ritme, tempo, warna suara dan sebagainya.

Musik dapat dikatakan suatu hasil kreatifitas manusia, lahirnya musik keluar atas dorongan dari ide-ide atau emosi-emosi yang ada didalamnya, kemudian dituangkan dalam bentuk usaha menyusunkan nada, ritme, lagu, dan keharmonisan secara bersamaan sehingga dapat melahirkan keindahan dan kesenangan. Menurut Sidi Gazalba, "seni secara sederhana biasanya diartikan sebagai usaha untuk menciptakan bentuk-bentuk yang menyenangkan". ${ }^{10} \mathrm{Hal}$ ini mewujudkan sebuah kelebihan manusia bila dibandingkan dengan makhluk lainnya seperti hewan. Dengan keharmonisan akal dan hati manusia dapat berkreasi sedemikian rupa dengan menciptakan bentuk-bentuk atau hal-hal yang menyenangkan, baik itu yang berbentuk nyata ataupun abstrak.

Musik adalah suatu kreasi seni yang ditujukan untuk memperoleh nilai estetika (nilai yang mengandung kapasitas untuk menimbulkan tanggapan estetik atau pengalaman estetik, yang mengartikan pengalaman yang berkaitan dengan keindahan). ${ }^{11}$ Dengan

${ }^{9}$ Budilinggono, Bentuk dan Analisis Musik, (Jakarta: Departemen Pendidikan dan Kebudayaan, 1993), h. 1.

${ }^{10}$ Sidi Gazalba, Pandangan Islam Tentang Kesenian, (jakarta: Bulan Bintang, 1997), h. 20.

${ }^{11}$ Sidi Gazalba, Islam dan Kesenian; Relevansi Islam dan Seni Budaya, (Jakarta: Pustaka Alhusna, 1988), h.75. 
Mohammad Nawir, Mokh. Ulil Hidayat, Iskandar, Musik Sebagai...

nilai estetika tersebut orang dapat merasakan keindahan serta merasakan apa yang telah dirasakan oleh penciptanya melalui pesan dalam bentuk musik.

Keindahan merupakan naluri manusia, dengan aspek intuisi yang digunakan sebagai landasan penilaian estetika atau keindahan yang datang melalui indera-indera yang terdapat dalam diri manusia. Baik dalam indera pendengaran, indera penglihatan, dan indera-indera lainnya.

Melalui indera pendengaran, musik dapat dirasakan dan diresapi oleh hati. Dengan indera pendengaran, manusia merasakan unsurunsurnya ke dalam hati, perenungan di dalamnya dapat melahirkan rasa yang berbeda-beda dalam diri manusia, baik itu rasa yang menyenangkan atau sebaliknya rasa yang tidak menyenangkan, hal ini tergantung dalam keharmonisan antara musik dengan manusia itu sendiri. Bila musik tersebut dapat dirasakan yang menyenangkan, maka ia menikmati keindahan musik tersebut berawal dari nilai estetika, sebut saja suara musik yang merdu. Namun jika perhatian yang kurang dalam menikmati musik, dapat menimbulkan minus atau kurangnya nilai-nilai seni dari musik, hal ini dapat disebabkan dengan menghubungkannya dengan perkara-perkara lain yang terdapat di luarnya.

Unsur dasar struktur musik terdapat 2 kategori, yaitu: ujud dan motif. Ujud adalah satuan bunyi terkecil dalam sebuah komposisi musik yang belum mengandung pengertian musikal yang terdiri atas satu, dua, atau tiga nada. Sedangkan motif adalah satuan terkecil dalam sebuah komposisi musik yang mengandung pengertian musikal; bunyi-bunyian yang keluar, dan dapat diketahui atau ditangkan nilai musiknya. ${ }^{12}$

\footnotetext{
${ }^{12}$ Budilinggono, Bentuk dan...., h.2
} 
Musik secara besar dapat dicapai dengan menggabungkan kedua unsur tersebut "ujud dan motif" ke dalam satu kesatuan, namun terdapat beberapa persyaratan untuk dapat menghasilkan motif yang bagus, yaitu:

a. Minimal terdiri dari dua nada

b. Memiliki ritme yang jelas

c. Memiliki loncatan interval yang jelas, dan

d. Memiliki gambaran ide yang jelas. ${ }^{13}$

Motif-motif di atas, terdapat atau mengandung penjelasan. Pertama, apabila musik terdiri dari satu nada maka hanya akan memperoleh musik yang terdiri dari satu suara saja. Dengan ini satuan terkecil dari unsur musik ialah dengan adanya atau memiliki dua nada, dan lebih baik jikalau terdiri dari dua nada. Kedua,penjelasannya adalah ada suatu aturan tertentu dalam musik agar terdapat lantunan yang harmonis. Dengan adanya ritme yang terarah atau teratur, sehingga enak dan merdu untuk didengar. Ketiga, musik terdiri dari interval ataupun frase-frase tertentu, sebagai keseimbangannya dari ritme yang telah dibuat. Keempat atau yang terakhir, bahwa dalam setiap penuangan hasil karya, harus ada gambaran yang jelas sehingga orang lain dapat menangkap dan merasakan nilai keindahan.

Musik diharuskan memiliki nilai komunikasi antara pemusik (orang yang memainkan musik) dengan orang yang mendengarkannya. Nilai komunikasi tersebut dengan tujuan agar keduanya dapat memperoleh pengalaman estetika. Memperoleh nilai komunikasi, caranya serupa atau sama dengan menggunakan bahasa agar dapat

\footnotetext{
${ }^{13}$ Ibid.
} 
Mohammad Nawir, Mokh. Ulil Hidayat, Iskandar, Musik Sebagai...

dipahami; yakni dengan menyusun atau merangkai kata-kata atau frase, kemudian dijadikannya dengan kalimat, dan dari kalimat yang diucapkan orang lain dapat memahami tujuan dan maksudnya. Budilinggono mengatakan bahwa "kata-kata dirangkai menjadi frase dan dari frase menjadi kalimat. Sama halnya dengan musik diawali dari rangkaian motif-motif yang ada, menjadi suatu bentuk musik secara keseluruhan". ${ }^{14}$

Terdapat dua frase dalam musik, yaitu: frase tanya, dan frase jawab. Pertama, frase tanya ditandai dengan sebuah batas akhir yang member kesan berhenti sementara. Sedangkan yang kedua, frase jawab ditandai dengan batas akhir yang mempunyai kesan selesai.

Selain itu musik bisa pula disajikan ke dalam beberapa jenis, diantaranya:

a. Musik Vokal

Kata vokal berasal dari kata vocoal (Belanda), voca (Italia), voix (Perancis), voice (Inggris), yang memiliki makna suara. Musik vokal memiliki arah terhadap semua suara manusia. Dengan demikian musik vokal itu hanya mempergunakan suara manusia atau nyanyian saja, tanpa diiringi alat musik. Hidangan musik vokal disebut dengan kata vokalia, dan mereka yang mendengarkan musik vokal disebut dengan sebutan vokalis. ${ }^{15}$

\section{${ }^{14}$ Ibid, h. 9}

${ }^{15}$ Murodi, Muatan-muatan Dakwah Dalam Lagu Ebiet G. Ade (Studi Analisis Tentang Muatan, Dakwah Dalam Lagu Ebiet G. Ade), (Karya Ilmiah Mahasiswa IAIN Sunan Gunung Jati), h.31. di unduh dari Ref: (http://parapemikir.com /tradisi-ilmiahislam), diakses pada tanggal 08 Mei 2016, pukul 13.45 WITA 


\section{b. Musik Instrumental}

Instrumental berasal dari sebuah kata Instrument (Italia), yang mempunyai arti alat. Maksud dalam musik instrumental disini adalah alat musik seperti biola, terompet, dan alat musik lain-lainnya. Musik instrumental dalam penyajiannya, hanya menggunakan alat-alat musik saja tanpa ada nyanyian. Hidangan musik Instrumentalia, sedangkan yang menghidangkannya disebut dengan sebutan instrumentalis. ${ }^{16}$

c. Musik Campuran

Musik campuran adalah musik yang disatukan dari keduanya, yaitu musik vokal dan musik instrumental yang disajikan secara bersamaan atau bersama-sama. Pada umumnya yang dipentingkan adalah vokalnya, sedangkan instrumental hanya pengiring saja. Dalam pelaksanaanya dapat dilakukan oleh banyak orang, dua orang, hingga satu orang, jika ia memainkan musik sambil bernyanyi. ${ }^{17}$

Jadi, bermain musik tidak hanya memainkan alat musik atau instrumennya saja, akan tetapi dengan mengeluarkan nyanyian juga merupakan bagian dari bermain musik. Dengan menyatukan kedua penyajian tersebut, akan diperoleh permainan musik yang lengkap dan beragam menjadi satu kesatuan yang terpadu.

\section{Musik sebagai Media Dakwah.}

Musik memiliki hubungan yang erat dengan kehidupan manusia, musik juga memiliki hubungan erat dengan dakwah. karena keduanya memiliki kelebihan dan manfaat tersendiri. hal ini disebapkan musik memiliki beberapa kelebihan karena musik bersifat nyaman,

\footnotetext{
${ }^{16} \mathrm{Ibid}$.

${ }^{17}$ Ibid, h. 32
} 
Mohammad Nawir, Mokh. Ulil Hidayat, Iskandar, Musik Sebagai...

menenangkan, membuat rileks, berstruktur, dan universal. Hal ini dibuktikan dengan beberapa pandangan para filusuf muslim terdahulu, musik dijadikan sebagai terapi kesehatan. Terapi musik sangat mudah diterima oleh organ pendengaran kita dan kemudian melalui saraf pendengaran disalurkan kebagian otak yang memproses emosi. ${ }^{18}$

Dalam dakwah ada proses bimbingan konseling-adalah proses pemberian bantuan secara terarah, kontinu dan sistematis kepada setiap individu $^{19}$. Dengan cara memberikan masukan, saran, pencerahan, dan motivasi agar dia mampu mengembangkan fitrah agamanya dan mampu meningkatkan nilai-nilai yang terkandung dalam Alquran dan Alhadis.

Tokoh spiritual Islam masa lalu menggunakan musik untuk memunculkan keseimbangan dalam hidup setelah aktifitas keseharian mereka. Bagi para sufi kesenian ini adalah kesenian paling suci, dengan bantuan musik mereka bermeditasi, dengan memainkan musik tertentu yang memberikan efek tertentu bagi perkembangan individu. Penyair besar dari Persia yang bernama Jalal ad-Din Rumi, biasa menggunakan musik untuk meditasinya. Dengan bantuan musik dia menenangkan diri dan mengendalikan aktifitas tubuh dan pikiran.

Berdasarkan beberapa literatur tokoh-tokoh seperti Al-Kindi dan Al-Farabi merupakan ilmuwan muslim yang megembangkan musik sebagai alat terapi. Pada abad ke 9, Al-Kindi sudah mencoba

\footnotetext{
${ }^{18}$ Samuel Haakim, Efek Mozarat Dan Terapi Musik Dalam Kesehatan, Fakultas Kedokteran Universitas Indonesia, (http://nesion23red.multiply/com/jurnal/item6) di akses tanggal 7 Agustus 2016).

${ }^{19}$ Samsul Munir Amin, Bimbingan Konseling Islam, (Jakarta:Amzah, 2013 Ed. 1, Cet. 2) h. 23 .
} 
menerapkan pengobatan dengan musik kepada seorang anak yang lumpuh total.

Selanjutnya, pemanfaatan musik sebagai terapi berkembang pesat diera kejayaan Turki Usmani pegembangan terapi musik ini terus berlanjut hingga menyebar keseluruh dunia, termaksuk Indonesia ${ }^{20}$.

Saat ini musik dikalangan masyrakat dinikmati dengan bentuk yang berbeda sesuai dengan kondisi hati yang tenang. Pegelompokan mengenai kecenderungan seseorang diklasifikasikan menjadi 3 bentuk : a) Penikmat musik, b) Pencinta musik, c) Pekerja musik atau seniman musik

Dalam hal ini penulis ingin memberikan gambaran bahwa musik ini erat kaitanya dengan psikologi seseorang sehingga bisa membuat orang menjadi tenang, semangat, dan memberikan motifasi untuk hidup. Sejalan dari itu bimbingan konseling islam memiliki hubungan erat dengan musik, sederhananya ialah memiliki fungsi yang sama.

a. Jenis-jenis Musik Terapi

Ada beberapa jenis musik yang dijadikan sebagai pendekatan bimbingan konseling Islam seperti: 1) Musik Klasik, 2) Musik Alam, 3) Musik Tradisional, 4) Musik Islami

1) Musik Klasik

Musik klasik ialah perpaduan instrumen yang menggunakan violin, biola, pianao dan celo sebagai alat musiknya. Ciri utama dari musik klasik adalah memiliki sedikit iringan vokal atau bahkan terkadang tidak memiliki iringan vokal pada musiknya. Kemudian ciri berikutnya diiringi dengan menggunakan orkestra.

Dalam hal ini, Don Cambele mengatakan bahwa

${ }^{20}$ Samuel Hakim, Efek Mozarat..., h. 15 
Mohammad Nawir, Mokh. Ulil Hidayat, Iskandar, Musik Sebagai...

"musik klasik bisa memberikan rangsangan, yang nantinya akan menghasilkan efek mental dan fisik, yaitu antara lain dapat menutupi bunyi dan perasaan yang tidak menyatakan, musik dapat memperlambat dan menyeimbangkan gelombang otak, musik mempengaruhi pernafasan, musik mempengaruhi denyut jantung, nadi dan tekanan darah, musik mempengaruhi ketegangan otot dan memperbaiki gerak dan kondisi tubuh, musik mempengaruhi suhu badan, musik dapat mengatur hormonhormon yang berkaitan dengan stres, musik mengubah presepsi kita tentang ruang, musik mengubah presepsi kita tentang waktu, serta musik meningkatkan daya tahan tubuh" 21 .

2) Musik Alam

Musik alam adalah jenis musik yang bersifat alamiya, karena jenis musik ini dihasilkan dari suara alam sekitar. Dengan kata lain musik alam adalh musik yang berasal dari lingkungan, salah satu contoh musik yang dapat dijadikan terapi adalh suara ombak.

3) Musik Tradisional

Musik tradisional adalh musik yang berasal dari berbagai daerah. Cri khas dari jenis musik ini terletak pada suara yang dihasilkan pada setiap alat musiknya. Musik ini dapat mempengaruhi pisikologi sesorang ketika mendengarkan suara yang dihasilkan contonya dengan alat musik kakula, lalove, dan gimba dapat merubah suasaana diri seseorang.

4) Musik Islami

Musik islami adalah musik yang bernuansa rohaniya, sehingga bagi siapa saja yang mendengarkan jenis musik ini akan tersentuh hatiny. Musik ini bisa mempengaruhi jiwa seseorang sehingga akan

\footnotetext{
${ }^{21}$ Dewi Satya Ningsi dan Tamsil Muis, "Pengaruh Penerapan Kombinasi Musik Klasik Dan Latihan Relaksi Untuk Menurunkan Stress Pada Siswa Kelas XI IPA 2 SMA Insentif Taruna Pembangunan Surabaya", Penelitian Dan Bimbingan Konseling, (Februari, 2012), h. 3
} 
mengambarkan tentang kehidupan. Jenis musik ini menggunakan instrumen renungan dan lagu.

Terapi musik islami ditandai dengan penggunaan jenis musik yang digunakan sebagai terapi, yaitu musik Islam atau musik rohani yang dapat membuat klien "berpijak ke tanah" dengan membimbing kearah perasaan damai yang mendalam serta kesadaran rohani. ${ }^{22}$ Dengan menggunakan terapi musik ini kita akan merasahkan sensasi yang sangat baik bagi kesehatan dalam berfikir dan dalam melakukan kegiatan kita sehari-harinya.

Selain dari itu semua jenis musik sebenarnya dapat digunakan sebagai terapi, seperti lagu-lagu relaksi, lagu populer maupun lagu atau musik klasik. Akan tetapi yang paling dianjurkan adalh musik atau lagu dengan tempo sekitar 60 ketukan per menit yang bersifat rileks. ${ }^{23}$

Tidak terkecuali dengan jenis musik yang bernuansa Islami, religi atau rohani.

Dengan demikian telah tergambarkan secara sederhana yaitu bentuk dan jenis musik yang digunakan sebagai pendekatan terapi bimbingan konseling Islam. Hal ini membuktikan bahwa sejak dari dulu musik tida sekedar hiburan saja, melainkan dapat digunakan sebagai alat terapi bagi manusia, sebagai obat penenang, dan sebagi alat prufikasi penyucian jiwa.

Menurut Fedrasi dalam Djohan;

"Terapi Musik Dunia (WMFT) terapi musik adalah penggunaan musik dan/atau elemen musik (suara, irama, melodi, dan harmoni)

98

${ }^{22}$ Don Campbell, Efek Mozarat, (Jakarta: Gren Media Pustaka Utama, 2001), h.

${ }^{23}$ Rizem Azid, Sehat Dan Cerdas Dengan Terapi Musik, (Yogyakarta: Laksana, 2011), h. 103 
Mohammad Nawir, Mokh. Ulil Hidayat, Iskandar, Musik Sebagai...

oleh seorang terapis musik yang telah memenuhi kualifikasi, terhadap klien dan sekelompok dalam proses membangun komunikasi, untuk membangun relasi interpersonal, belajar, meningkatkan mobilitas, mengunkapkan ekspresi, menata diri atau untuk mencapai berbagai tujuan terapi lainya ${ }^{24}$.

b. Manfaat Terapi Musik

Ada beberapa manfaat dari terapi musik menerut Djohan sebagai berikut $^{25}$ :

1) Relaksasi Mengistirahatkan Tubuh dan Pikiran

Manfaat yang pasti dirasakan setelah melakukan terapi musik dalah perasaan rileks, tubuh lebih bertenagah dan fresh. Terapi musik memberikan kesempantan bagi tubuh untuk mengalami relaksi (istirahat) yang sempurna. Dan seluruh sel dalam tubuh mengalami re-produksi, penyembuhan alami berlangsung, produksi hormon tubuh diseimbangkan dan pikiran mengalami penyegaran. Sehingga semua bebean pikiran yang kita rasakan akan berkurang.

2) Meningkatkan Kecerdasan

Sebuah efek terapi musik yang bisa meningkatkan intelegensi seorang disebut Efek Mozarat. Hal ini telah diteliti oleh Frances Rausher dkk, dari Universitas California. Penelitian yang lain juga membuktikan bahwa masa dalam kandungan dan bayi adalah waktu yang paling tepat untuk menstimulasi otak anak ingin menjadi cerdas. Hal ini karaena otak anak dalam keadaan pembentukan, sehingga akan baik apabila mendapatkan rangsangan yang positif. Ketika seorang ibu yang hamil sering mendengarkan terapi musik, janin yang di dalam kandunganya 28

${ }^{24}$ Djohan, Terapi Musik: Teori Dan Aplikasi, (Yogyakarta: Galang Press, 2006), h.

${ }^{25}$ Ibid, h. 65. 
ikut mendengarkan. Dan otak janinpun akan tersitimulasi untuk belajar dalam kandungan.

\section{3) Menigkatkan Motivasi}

Motivasi adalh hal yang bisa dilahirkan dengan perasaan dan mood tertentu. Motifasi yang ada dalam diri seseorang akan muncul ketiaka ada semangat yang di banggun dalam diri. Dan begitupun sebaliknya jika motivasi terbelengu maka semangatpun akan luntur, lemas, dan tak ada tenaga untuk beraktivitas. Dari beberapa pengamatan, ternyata ada jenis musik tertentu yang bisa membangkitkan motivasi, semangat dan level seseorang salah satunya jenis musik Rook.

4) Pegembangan Diri

Ternyata musik juga bisa mempengaruhi pegembangan diri seseorang. Musik yang didengarkan oleh seseorang juga bisa menentukan kualitas pribadi seseorang. Hasil penelitian menujukan orang yang memiliki masalah perasaan, biaanya cenderung mendengarkan musik yang sesuai dengan perasaanya. Misalnya orang yang sedang putus cinta cenderung mendengarkan musik atau lagu tentang putus cinta atau sakit hati. Dan dari hasil pengamatan masalahnya semakin parah. Dengan demikian setiap orang memiliki kepribadian yang diinginkan dengan cara mendengarkan musik dengan tepat dan sesuai.

5) Meningkatkan Daya Ingat

Terapi musik juga bisa meningkatkan daya ingat dan menjegah kepikunan. Hal tersebut bisa terjadi karena bagian otak yang memproses musik berdampingan dengan memori otak kita. Sehingga ketika seseorang melatih otak dengan terapi musik, maka secara otomatis 
Mohammad Nawir, Mokh. Ulil Hidayat, Iskandar, Musik Sebagai...

memori otak manusia akan terlatih dan daya ingat akan bertambah. Atas dasar inilah banyak orang yang menggunakan terapi musik di sekolah-sekolah moderen di Amerika dan Eropa dengan tujuan mereka menikatkan daya ingat dan prestasi akademik siswa. Selain itu di pusat rehabilitasi, terapi musik banyak digunakan untuk menagani masalah kepikunan dan kehilang ingatan.

6) Kesehatan Jiwa

Musik membuat rasa tenang, sebagai pendidikan moral, mengendalikan emosi, sebagai pegembangan spritual, menyembukan ganguan pisikologis, pernyataannya tentu saaja berdasarkan pegalamanya dalam menggunakan musik sebagai terapi. Dan saat ini di zaman moderen terapi musik banyak digunakan oleh pisikolog maupun psikiater untuk mengatasi berbagai macam gangguan kejiwaan, gangguan mental dan gangguan pisikologi.

7) Mengurangi Rasa Sakit

Musik bekerja pada sistem saraf otonom yaitu bagian sistim saraf yang bertanggung jawab mengontrol tekakan darah, denyut jantung dan fungsi otak, serta mengontrol perasaan dan emosi. Dan kedua sistem tersebut bereaksi sensitif kepada musik. Ketika kita merasa sakit, kita menjadi takut, frustasi dan marah sehingga kita meneggangkan otot tubuh, dan hasilnya rasa sakit semakin parah. Mendengarkan musik secara teratur membuat tubuh rileks secara fisik dan mental. Sehingga membantu menyembuhkan dan menbuat feres kembali otak kita dalam berfikir. Dalam proses persalinan, terapi musik berfungsi mengatasi rasa cemas dan mengurangi rasa sakit. 
8) Meningkatkan Olahraga

Mendengarkan musik ketika sedang olahraga, dapat memberikan dorongan dalam diri untuk lebih semangat dan lebih aktif dalam melakukan gerakan-gerakan tubuh sehingga dalam setiap geraknya akan lebih aktif dan penuh penghayatan yang tinggi.

\section{Siswa Tunagrahita}

\section{Pengertian Siswa Tunagrahita}

Tunagrahita adalah istilah yang digunakan untuk menyebut siswa yang mempunyai kemampuan intelektual di bawah rata-rata. Dalam kepustakaan bahasa asing di gunakan istilah-istilah mental retardation, mentally retarded, mental deficiency, mental defective, dan lain - lain. ${ }^{26}$

Istilah tersebut sesungguhnya memiliki arti yang sama yang menjelaskan kondisi siswa yang kecerdasannya di bawah rata-rata dan di tandai dengan keterbatasan inteligensi dan ketidakcakapan dalam interaksi sosial. Siswa tunagrahita atau dikenal juga dengan istilah terbelakang mental karena keterbatasan kecerdasannya mengakibatkan dirinya sukar untuk mengikuti program pendidikan di sekolah biasa secara klasikal, oleh karena itu siswa terbelakang mental membutuhkan layanan pendidikan secara khusus yakni disesuaikan dengan kemampuan siswa tersebut.

Jadi dapat disimpulkan bahwa tunagrahita adalah salah satu bentuk gangguan yang dapat ditemui diberbagai tempat dengan karakteristik penderitaannya yang memiliki tingkat kecerdasan dibawah

${ }^{26}$ Sutjihati Somantri, Psikologi Anak Luar Biasa, (Bandung: Refika Adiitama, 2006), h. 64. 
Mohammad Nawir, Mokh. Ulil Hidayat, Iskandar, Musik Sebagai...

rata-rata (IQ dibawah 75) dan mengalami kesulitan dalam beradaptasi maupun dalam melakukan aktivitas sosial lingkungannya.

\section{Klasifikasi Siswa Tunagrahita}

Beberapa klasifikasi Siswa Tunagrahita yang diukur melalui IQ:

a. Ringan (Debil, IQ 51-70)

Siswa Tunagrahita mampu didik (debil) adalah siswa tunagrahita yang memiliki banyak kelebihan dan kemampuan. Mereka tidak mampu mengikuti program sekolah biasa, tetapi masih memiliki kemampuan yang dapat dikembangkan pada siswa tunagrahita mampu didik, antara lain: membaca, menulis, mengeja, berhitung, dan lain-lain. Sehingga siswa tunagrahita debiberarti siswa tunagrahita yang dapat dididik secara minimal dalam bidang-bidang akademis, sosial, dan pekerjaan. ${ }^{27}$

b. Sedang (Imbecile, IQ 36-51)

Siswa Tunagrahita mampu latih (imbecile) adalah siswa Tunagrahita yang memiliki kecerdasan sedemikian rendahnya, sehingga tidak mungkin untuk mengikuti program yang diperuntukkan bagi siswa Tunagrahita mampu didik. Namun kelemahannya mereka tidak begitu mahir dalam menulis, membaca, dan berhitung. Sehingga anak tunagrahita imbecil berarti siswa Tunagrahita yang tidak mampu dididik seperti siswa Tunagrahita debil. Siswa Tunagrahita tersebut biasanya hanya diajarkan seperti menyanyi, menari, dan bermain alat musik. ${ }^{28}$

Beberapa kemampuan siswa Tunagrahita mampu latih yang perlu diberdayakan:

${ }^{27}$ Aulia Erfan, Pembelajaran Musik Untuk Anak Tunagrahita di Bengkel Sekolah Musik SLB Negeri Semarang, Skripsi tidak diterbitkan (Semarang, Jurusan Pendidikan Seni Drama Tari dan Musik, 2015), h. 23

${ }^{28}$ Ibid. 
1) Belajar mengurus diri sendiri, contohnya: makan, pakaian, tidur, ataumandisendiri.

2) Belajar menyesuaikan lingkungan rumah atau sekitarnya

3) Mempelajari kegunaan ekonomi di rumah, di bengkel kerja, atau di lembagakhusus.

Sehingga siswa Tunagrahita mampu latih berarti siswa Tunagrahita yang hanya dapat dilatih untuk mengurus diri sendiri melalui aktivitas kehidupan sehari-hari, serta melakukan fungsi sosial kemasyarakatan menurut kemampuannya.

c. Berat atau Idiot (IQ 0-25)

Siswa Tunagrahita mampu rawat (idiot) adalah siswa Tunagrahita yang memiliki kecerdasan sangat rendah, sehingga siswa tidak mampu mengurus diri sendiri atau bersosialisasi dan mengurus kebutuhan diri sendiri sangat membutuhkan orang lain. Asumsi siswa Tunagrahita sama dengan siswa idiot tepat digunakan jika siswa Tunagrahita yang dimaksud tergolong dalam Tunagrahita berat. ${ }^{29}$

Siswa Tunagrahita mampu rawat dalam hal ini Idot adalah mereka yang kecerdasanya sangat rendah, mereka tidak mampu mengurus diri sendiri dan sulit untuk bersosialisasi dengan lingkungannya. Dikarnakan kecerdasan yang mereka miliki sangat rendah.

\section{Karakteristik Tunagrahita}

Karakteristik anak dengan hendaya perkembangan tunagrahita, meliputi hal-hal sebagai berikut:

a. Mempunyai dasar secara fisiologis, sosial, dan emosional sama seperti anak-anak yang tidak menyandang tunagrahita.

${ }^{29}$ Ibid, h. 24 
Mohammad Nawir, Mokh. Ulil Hidayat, Iskandar, Musik Sebagai...

b. Selalu bersifat eksternal locus of control sehingga mudah sekalimelakukan kesalahan (expectancy for filure).

c. Suka meniru perilaku yang benar dari orang lain dalam upaya mengatasi kesalahan-kesalahan yang mungkin ia lakukan (outerdirectedness).

d. Mempunyai perilaku yang tidak dapat mengatur diri sendiri.

e. Mempunyai permasalahan berkaitan dengan perilaku sosial (socialbehavioral).

f. Mempunyai masalah berkaitan dengan karakteristik belajar.

g. Mempunyai masalah dalam bahasa dan pengucapan.

h. Mempunyai masalah dalam kesehatan fisik.

i. Kurang mampu untuk berkomunikasi.

j. Mempunyai kelainan pada sensori dan gerak.

k. Mempunyai masalah berkaitan dengan psikiatrik, adanya gejalagejaladepresif. $^{30}$

Dari uraiaan di atas dapat kita pahami bahwa Siswa Tunagrahita adalah mereka yang memiliki kecerdasan yang rendah sehingga kesulitan yang mereka hadapi yaitu kesulitan dalam bersosialisasi dengan lingkungannya.

Tamsih Udin AM dan E. Tejaningsih di dalam bukunya yang berjudul "Dasar dasar Pendidikan Luar Biasa SPG/SPO/KPG" menyebutkan ciriciri anak tunagrahita, yaitu:

a. Anak tunagrahita ringan

Keadaan fisik anak tunagrahita ringan (mampu didik) pada umumnya masih sama dengan anak normal maupun anak lambat

\footnotetext{
${ }^{30}$ Bandi Delphie, Pembelajaran Anak Berkebutuhan Khusus, (Bandung: PT. Refika Aditama, 2006), h.17
} 
belajar. Bentuk kepala, mata, hidung, bentuk tubuhnya tidak ada bedanya. Jadi, dengan melihat keadaan fisik saja tidak dapat membedakan mana anak yang mampu didik, mana anak yang menentukan seseorang anak itu tergolong mampu didik setelah mengadakan observasi dan tes psikologi. ${ }^{31}$

b. Anak tunagrahita sedang

Keadaan fisik anak mampu latih (tunagrahita sedang) pada umumnya berbeda dengan anak normal. Letak perbedaannya mungkin pada kepala, mata, bentuk muka, mulut, dan pada bentuk badannya. Ada yang tubuhnya kecil, bentuk mukanya bulat telur, bibirnya tebal dan selalu terbuka, kadang-kadang air liurnya selalu keluar, serta adapula yang kepalanya lebih besar dari kepala anak normal dan tidak seimbang dengan badannya. Para guru SLB-C dan para pengasuh yang sudah berpengalaman akan dengan mudah mengenal anak mampu latih.

c. Anak tunagrahita berat

Keadaan fisik anak perlu rawat (tunagrahita berat) seperti halnya anak mampu latih. Beda dengan anak mampu didik dan anak lambat belajar, bahkan perbedaannya lebih menonjol. Orang awam akan dapat membedakan anak perlu dirawat daripada anak normal. Akan tetapi, mereka tidak akan mengerti bahwa anak itu tergolong anak perlu rawat yang diketahuinya bahwa anak itu gila.

${ }^{31}$ Tamsih Udin AM dan E. Tejaningsih, Dasar-dasar Pendidikan Luar Biasa SPG/SPO/KPG, (Cet. I; Bandung: Epsilon Grup Bandung Anggota IKAPI, 1988), h. 4244 
Mohammad Nawir, Mokh. Ulil Hidayat, Iskandar, Musik Sebagai...

\section{Faktor-faktor Penyebab Tunagrahita}

a. Faktor Prenatal

Periode prenatal/sebelum kelahiran banyak faktor yang dapat menyebabkan tunagrahita diantaranya kelainan pada kromosom trisonomi 21, perkawinan sedarah, kehamilan yang tidak sehat, dan garis keturunan.

b. Faktor Natal

Periode natal/kelahiran juga penyebab kedua dari kecatatan. Faktor dalam kelahiran yang dapat menyebabkan kecacatan adalah lahir prematur, proses persalinan yang tidak normal, dan benturan benda keras pada kepala bayi.

M. Efendi berpendapat bahwa siswa Tunagrahita adalah siswa yang memiliki taraf kecerdasan yang sangat rendah sehingga untuk meniti tugas perkembangannya ia sangat membutuhkan layanan pendidikan dan bimbingan secara khusus. ${ }^{32}$

c. Faktor Post Natal

Kelahiran yang disebabkan pada penyakit anak-anak, kurang gizi, kecelakaan, dan perawatan bayi yang tidak sehat. ${ }^{33}$ Ini terjadi karena kuranya gizi, atau perawatan bahkan ini terjadi akibat dari kecelakaan sehingga menimbulkan kecatataan anak dari beberapa factor ini dapat ditarik kesimpulan bahwa faktor post natal adalah faktor yang diakibatkan kurangnya gizi, kurangnya perhatian dan kecelakaan.

Menurut Grossman yang dikutip oleh Hadis, kelompok siswa yang mengalami keterbelakangan mental atau disebut retardasi mental

${ }^{32}$ Efendi, M. Pengantar Psikopedagogik Anak Berkelainan, (Jakarta: Bumi Aksara, 2006), h. 110.

${ }^{33}$ Ibid, h. 25. 
didefinisikan sebagai kelompok siswa yang memiliki fungsi intelektual umum dibawah rata-rata secara signifikan yang berkaitan dengan gangguan dalam penyesuaian perilaku yang terjadi selama periode perkembangan.Tunagrahita ditandai oleh ciri utamanya yaitu kelemahan dalam berfikir atau bernalar, serta kemampuan belajar dan beradaptasi sosialnya dibawah rata-rata. ${ }^{34}$

Bagi siswa yang meiliki keterbelakangan mental ini adalah mereka yang memiliki kesulitan dalam mengurus diri sendiri ataupun kesulitan dalam bersosialisasi dengan lingkungannya. Karena cerdasan intelektualnya di bawah rata-rata, mmbuat mereka kesulitan dalam beradaptasi dengan lingkungannya sehingga memerlukan proses yang panjang.

\section{Musik Sebagai Media Dakwah di Panti Sosial Bina Grahita Nipotowe Palu}

Musik dijadikan sebagai dakwah dengan melakukan pendekatan bimbingan bagi siswa tuna grahita di panti sosial bina grahita nipotowe palu. Karena itu pendekatan melalui media musik menjadi salah satu pilihan bagi pembimbing dalam melakukan aktifitas pemberdayaan siswa tuna grahita. Berdasarkan hasil observasi dan pengamatan di lapangan peneliti melihat media musik yang digunakan dalam setiap pendekatan memiliki jenis musik yang berbeda.

\footnotetext{
${ }^{34}$ Hadis, Abdul, Pendidikan Anak Berkebutuhan Khusus Austik,(Bandung:Alfabeta, 2006), h. 6.
} 
Mohammad Nawir, Mokh. Ulil Hidayat, Iskandar, Musik Sebagai...

Jenis Musik yang biasa digunakan sebagai media dakwah dalam melakukan pendekatan bimbingan maupun konseling terhadap siswa tunagrahita adalah;

1). Musik Dangdut

Musik dangdut salah satu jenis musik yang digunakan dalam pendekatan bimbingan yang memberikan semangat atau motivasi bagi mereka. hal ini terlihat dari ekspresi wajah mereka yang penuh dengan kegembiraan dalam mengikuti musik tersebut.

Bardasarkan pengamatan peneliti dan wawancara dengan informan bahwa pendekatan musik dangdut ini menjadi salah satu pendekatan yang membuktikan betapa antusiasnya mereka dalam mengikuti setiap kegiatan yang diberikan.

Berdasarkan pengamatan peneliti melihat dan mengamati ternyata ada proses perubahan mood atau semangat ketika di lapangan. Misalnya ketika mereka diputarkan dengan musik dangdut, mereka akan kelihatan sangat antusias dan semangat dalam mengikuti musik itu sampai selesai.

Berbanding terbalik ketika mereka diputarkan dengan jenis musik yang lain, mereka akan kelihatan kurang bersemangat dan biasanya, kebanyakan dari mereka hanya duduk dan menikmatinya saja sampai musik selesai. Begitupun dengan jenis-jenis musik yang lain masing masing memiliki kelebihan dan kekurangannya tersendiri.

Berdasarkan pengamatan peneliti tergantung dari jenis musiknya seperti apa, dan tergantung dari arasemen musiknya yang membuat mereka bisa menikmati musik itu dan menyukai musik itu. semua jenis memiliki perbedaan dan pengaruh tersendiri dalam mempengaruhi mereka. 


\section{2) Musik Pop}

Musik pop termaksud dari pendekatan musik yang digunakan bagi siswa tuna grahita. karena dalam melakukan proses bimbingan, penggunaan musik tentulah dibutuhkan ketika dalam keadaan dan saat yang tertentu, memancing mood siswa tuna grahita sebagian dari mereka memiliki kesukaan dengan musik ini.

Dan berdasarkan apa yang dilihat di lapangan setiap jenis lagu yang diputar bagi mereka ternyata mempunyai pengaruh bagi mereka. seperti apa yang digambarkan peneliti melalui skripsi ini.

Seperti peneliti mengamati ketika di lapangan khususnya bagi siswa tuna grahita, ketika musik pop di putar dan dinyanyikan lagunya. Hanya sebahagian dari mereka yang ikut dan sebagianya hanya duduk dan menonton saja. Ternyata setiap perubahan musik ini mempunyai pengaruh bagi siswa tuna grahita, seperti ditandai dengan perubahan pisikologis dan perubahan moot atau semangat dari mereka.

Berdasarkan apa yang dikatakan di atas dapat dipahami bahwa setiap musik memiliki kecenderungan untuk menarik daya tarik seseorang, tergantung dari mood siswa tuna grahita disesuaikan dengan kondisi yang ada. Bagi siswa tuna grahita mereka tentunya membutuhkan semangat dari apa yang mereka rasakan, mereka lihat, dan mereka alami akan lebih baik ketika pendekatan musik ini digunakan bagi mereka.

3. Musik Klasik.

Musik klasik adalah jenis musik yang banyak digunakan sebagai alat terapi, jenis dari musik ini seperti suara dari alam, suara orgen, biola, gitar, suling, musik-musik suasana dan musik instrumental. 
Mohammad Nawir, Mokh. Ulil Hidayat, Iskandar, Musik Sebagai...

Kelebihan dari musik ini memberikan ketenangan pikiran, membuat hati nyaman, dan bisa membuat orang tenang.

Berdasarkan pengamatan peneliti jenis musik ini berpengaruh bagi sisw tuna grahita ketika sedang dalam keadaan santai dan tenang. Musik ini memberikan sensasi ketenangan sehingga digunakan sebagai pengantar tidur. Dalam musik ini peneliti mengamati bahwa musik klasik digunakan ketika mereka tidak dalam keadaan beraktifitas. Dengan demikian sesuai apa yang dikatakan para ahli, peneliti memberikan kesimpulan bahwa jenis musik klasik memberikan efek mozarat, kenyamanan dan ketenangan yang ditawarkan. Musik klasik memberikan pengaruh yang positif bagi siswa tuna grahita. Dengan adanya jenis musik klasik memberikan warna lain dari jenis musik sebelumnya. Musik klasik memberikan ketenangan dan kenyamanan pikiran ketika seseorang mendengarkan musik ini, beban yang ada dalam pikirannya berkurang.

\section{Musik Islami}

Musik ini memjadi salah satu media dakwah, karena memiliki nuansa Islami dan memiliki pesan-pesan yang positif dalam setiap lagu yang diputarkan. Ketika jenis musik ini yang dijadikan sebagai media dakwah terlihat ada suasana yang berbeda dari pendekatan musik sebelumnya. Berlandaskan pengalaman sebelumnya sewaktu peneliti melakukan Kuliah Kerja Profesi di tempat penelitian tersebut. Peneliti melihat dan mengamati bahwa ternyata pendekatan musik Islami inilah ynag sangat efektif bagi siswa tuna grahita. Selain itu pendekatan melalui lagu-lagu ataupun musik Islami sangat mempengaruhi pisikologi dan mental mereka. Sehingga memudahkan kita untuk berkomunikasi dengan mereka, dan apapun yang kita bicarakan akan mudah masuk. 
Pendekatan jenis musik Islami memberikan jalan dalam melakukan pendekatan bimbingan konseling, selain dari jenis musik ini mendukung suasana yang ada. Lagu-lagu yang mempunyai pesan agama bisa memberikan pencerahan bagi siswa tunagrahita melalu pendekatan musik. Karena akan berbeda kesannya dan hasilnya apabila dalam melakukan bimbingan/dakwah tampa menggunakan musik dengan menggunakan musik jelas perbedaan sangat jauh sekali. Musik Islami memberikan dorongan spiritual bagi mereka dalam keseharian siswa tunagrahita dalam beraktifitas.

Dengan beberapa penjelasan di atas dapat memberikan gambaran bahwa pendekatan musik Islami ini memberikan dorongan spiritual, memberikan pencerahan, dan memberikan pengenalan untuk mengetahuhi agamanya. Meski dengan keadaan siswa tuna grahita yang memiliki banyak kekurangan dan kecerdasan di bawah rata-rata tetapi tidak menjadi penghalang bagi mereka untuk mengenal Agamanya dan Tuhanya.

\section{Pemanfaatan Musik Sebagai Media Dakwah dalam Pemberdayaan Siswa Tunagrahita di Panti Sosial Bina Grahita Nipotowe Palu}

Musik memiliki peranan penting bagi siswa tuna grahita, kerena dalam melakukan bimbingan konseling Islam sebagai bentuk lain dari dakwah, tentunya seorang konselor harus memiliki keterampilan dan pendekatan yang tepat dalam proses bimbingan konseling. Keterampilan dan pendekatan inilah yang dijadikan senjata ampuh bagi seorang konselor dalam mengenali dan menggali permasalahan. Dalam hal ini seorang konselor dituntut harus memiliki keterampilan yang tepat untuk 
Mohammad Nawir, Mokh. Ulil Hidayat, Iskandar, Musik Sebagai...

melakukan bimbingan bagi siswa tuna grahita. Seperti yang kita ketahui bahwa siswa tuna grahita adalah mereka yang memiliki kemampuan intelektual di bawa rata-rata, untuk itu bagi mereka seorang konselor dalam melakukan pendekatan yang sifatnya klasikal, terlihat sedikit memiliki kesulitan dalam memahami apa yang kita berikan. Dengan demikian pendekatan yang dilakukan haruslah tepat bagi mereka.

Dalam hal ini pendekatan musik menjadi salah satu pendekatan bimbingan konseling Islam yang efektif bagi siwa tuna grahita. Musik adalah salah satu pendekatan yang dilakukan bagi lembaga Panti Sosial Bina Grahita Nipotowe dalam memudakan semua proses kegiatan di lembaga tersebut.

Berdasarkan pengamatan peneliti bahawa musik menjadi media yang sangat penting dalam kehidupan keseharian bagi siswa tuna grahita dalam melakukan setiap aktifitas sehari-hari. Selain itu musik juga berperan penting dalam proses kegiatan keterampilan pemberdayaan bagi siswa tuna grahita Nipotowe Palu. Terlihat dari beberapa kejadian-kejadian di lapangan ketika sedang dalam proses memulai kegiatan keterampilan di ruangan 09:30 WITA, ketika musik diputarkan dalam ruangan, mereka akan segera memasuki ruang keterampilan tanpa harus dipanggil satu persatu dalam asramanya. Ketika mereka mendengarkan suara musik yang keras dalam ruangan, tampa harus diperintah mereka akan segera datang kedalam ruangan tersebut.

Hal ini membuktikan bahwa musik memiliki peranan penting bagi mereka, dan menjadi salah satu motivasi tersendiri bagi siswa tuna grahita. Dan membuktikan, bahwa musik juga adalah media yang digunakan sebagai pendekatan bimbingan konseling Islam dalam 
pemberdayaan siswa tuna grahita Nipotowe Palu. Menyambung dari pada itu musik juga memiliki kegunaan dan manfaaat serta peranan tersendiri dalam proses bimbingan konseling Islam. Sebagai mana penjelasan Ibu Umi Kiyah sebagai berikut:

1. Media Musik sebagai Stimulus Pemberdayaan Keterampilan Siswa

Dalam melakukan kegiatan pemberdayaan bagi siswa tuna grahita di Panti Sosial Bina Grahita Nipotowe Palu. Musik memiliki peran terpenting dalam mendampingi setiap kegiatan siswa tuna grahita tentunya kegiatan itu seperti menjahit di dalam ruangan. Musik dapat dimanfaatkan sebagai media dakwah dan atau bimbingan konseling Islam.

Ibu As Munarni, selaku pembimbing keterampilan menjahit dan salah seorang guru yang menggunakan musik di ruangannya sebagai media pendekatan dalam pemberdayaan siswa tuna grahita. Musik menstimuli semangat siswa untuk bekerja seperti ketika sedang latihan menjahit atau kegiatan-kegiatan lainnya. Bahkan ketika musik itu dimatikan mereka akan terlihat kurang semangat dan tidak serius dalam melakukan kegiatan bahkan ada yang sampai keluar ruangan. ${ }^{35}$

Dengan demikian gambaran tentang peranan musik telah jelas, dapat mempengaruhi setiap orang yang mendengarkannya sehingga membuat orang memiliki semangat, dan spirit dalam melakukan kegiatan-kegiatan tertentu. Bagi siswa tuna grahita musik adalah

${ }^{35}$ As Munarni,Selaku Pembimbing Keterampilan Menjahit, dan Menggunakan Musik Sebagai Pendekatan Dalam Pemberdayaan Siswa Tuna Grahita. “Wawancara” di Ruang Keterampilan Menjahit, Tanggal 18 Agustus, 2016. 
Mohammad Nawir, Mokh. Ulil Hidayat, Iskandar, Musik Sebagai...

motivasi dan penyemangat mereka dalam beraktifitas. Seperti yang kita ketahui siswa tuna grahita adalah mereka yang memiliki kecerdasan dibawah rata-rata, dan itu sebapnya bahwa mereka membutuhkan hiburan yang membuat mereka itu bisa memiliki semangat hidup dan merasakan kebahagiaan yang sama seperti halnya kita manusia yang normal. Dengan alasan inilah musik hadir sebagai media kebahagiaan dan kesenangan serta motivasi bagi mereka agar dapat bertahan dan semangat untuk hidup.

Menggunakan musik dapat membantu saya dalam berkomunikasi dengan mereka. mislnya ketika saya memberitahukan contoh cara untuk menjahit taplak meja dan aksesoris lainya, mereka memperhatikan tangan saya, walaupun dengan cara saya harus diulangulang bebrapa kali. Dan setelah sudah diperaktekan, mereka segera megerjakanya. Contoh yang lain juga seperti saya memberitahukan pada mereka disetiap lagu yang mempunyai pelajaran itu lagu Wali, lagu Islami, dan saya beritahukan sesuai dengan isi lagunya. ${ }^{36}$

Dengan demikian musik dapat memberikan bimbingan konseling Islam bagi setiap orang. melalui lagu-lagu yang bernuansa Islami ataupun lagu yang memiliki pesan moral dan etika. Sesuai dengan penjelasan di atas dapat disimpulkan bahwa ternyata musik juga memiliki bimbingan rohani tersendiri. Begitupun halnya dengan bimbingan konseling Islam memiliki kelebihan dan ciri khas tersendiri.

${ }^{36}$ As Munarni,Selaku Pembimbing Keterampilan Menjahit, dan Menggunakan Musik Sebagai Pendekatan Dalam Pemberdayaan Siswa Tuna Grahita. “Wawancara” di Ruang Keterampilan Menjahit, Tanggal 18 Agustus, 2016. 
2. Musik sebagai Keterampilan (Skill)

Dalam melakukan kegiatan atau proses pemberdayaan bagi siswa tuna grahita, pendekatan musik menjadi salah satu pendekatan yang dipilih untuk mendampingi siswa tuna grahita dalam melakukan kegiatan. Berdasarkan pengamatan peneliti di lapangan, bagi siswa tuna grahita mereka akan terlihat semangat dalam melakukan kegiatan apabila musik diputarkan sebagai pendamping mereka dalam melakukan kegiatan.

Kekurangan yang mereka miliki tidak menjadi penghambat bagi mereka dalam belajar untuk memainkan alat musik seperti sambra dan gitar. Ini dibuktikan peneliti di lapangan sebahagian dari mereka ternyata memiliki kemampuan dalam memaikan alat musik.

Dengan demikian dapat ditarik kesimpulan bahwa peranan musik memiliki kemampuan dalam berbagai hal, musik dapat mempengaruhi gaya hidup, dapat memberikan motivasi, digunkan sebagai pendekatan bimbingan konseling, memudahkan kita dalam melakukan aktifitas sehari-hari. Peranan musik sebagai pendekatan bimbingan konseling Islam memiliki kemampuan bimbingan yang berbeda dari pendekatan-pendekatan yang lainya. Karena pendekatan ini memiliki spirit yang berasal dari jiwa seni seseorang.

Sehingga pendekatan peranan musik ini memiliki kemampuan dalam meyentuh hati seseorang membuat nyamn dan senang serta gembira dalam perananya. Peranan musik ini memiliki motivasi yang berbeda dengan yang lainya karena ia lahir bersama jiwa dan hati serta perasaan seseorang menyentuh hati sehingga dapat menjadi sesuatu yang indah dan mempengaruhi setiap jiwa. 
Mohammad Nawir, Mokh. Ulil Hidayat, Iskandar, Musik Sebagai...

Hal ini terjadi karena keindahan dari musik itu sendiri membuat orang yang mendengarkanya menjadi tersetuh. Dengan demikian peranan musik sebagai pendekatan bimbingan konseling Islam menjadi spritual seni yang indah dalam hidup manusia. Pendekatan musik ini menjadikan media untuk memberikan jalan yang mudah bagi setiap bimbingan konseling Islam dalam melakukan peranannya.

Dari hasil wawancara tadi membuka cakrawala berfikir kita bahwa musik juga dapat berpengaruh terhadap kegiatan pekerjaan kita sebagai pendamping kita dalam melakukan aktifitas sehari-hari kita. Banyak orang menggunakan musik sebagai hiburan dalam melakukan pekerjaan. Dengan keterbatasan yang mereka miliki, tidak menjadi penghalang membatasi mereka untuk mengekspre sikan bakat mereka. berdasarkan penelusuran peneliti salah seorang siswa tuna grahita yang bernama Moh. Jefri pernah mengikuti lomba tarik suara. Ini membuktikan bahwa mereka memiliki bakat yang terpendam.

\section{E. Penutup}

Berdasarkan hasil penelitian yang dilakukan di Panti Sosial Bina Grahita Nipotowe Palu, dapat megemukakan beberapa kesimpulan dalam Peranan Musik Sebagai Media dakwah dalam Pemberdayaan Siswa Tuna Grahita sebagai berikut: pertama; Ada empat jenis musik yang digunakan dalam pemberdayaan siswa yaitu, Musik dangdut, Musik pop, Musik klasik dan Musik Islami atau kasidah.

Kedua; musik sebagai media dakwah dalam pemberdayaan siswa tunagrahita, memiliki manfaat yang besar bagi siswa tunagrahita, hal ini dibuktikan dengan antusias mereka dalam mendengarkan, mengikuti dan bahkan ada yang bisa dalam hal tarik suara serta 
memainkan Musik. Musik dapat memberikan dorongan motivasi tersendiri bagi siswa tuna grahita, Musik dapat memberikan semangat spiritual dan sebagai terapi bagi siswa tuna grahita. Musik memberikan hiburan bagi mereka dalam melakukan kegiatan sehari-harinya, Musik juga memberikan ketenangan bagai Siswa Tuna Grahita. Musik digunakan sebagai media dakwah dan dalam melakukan bimbingan konseling Islam bagi siswa tuna grahita, digunakan pula pendekatan pemberdayaan bagi siswa tuna grahita, Musik juga digunakan pembimbing sebagai alat terapi bagi siswa tuna grahita serta membantu daya ingat siswa tuna grahita.

\section{Daftar Pustaka}

A. Hellen, Bimbingan dan Konseling, Jakarta: Ciputat Pers, 2002.

Abdul, Pendidikan Anak Berkebutuhan Khusus Austik, (Bandung: Alfabeta, 2006.

Lubis, Akhyar, Syaiful Konseling Islami,Yogyakarta: eLSAQ Press, 2007

Al-Qardhawy Yusuf, Nasyid Versus Musik Jahiliyah, terj. H. Ahmad Fulex Bisri, H. Awan Sumarna, H Anwar Mustafa, Bandung: Mujahid Press, 2003.

Arifin M.Ed, Pokok-Pokok Bimbingan Dan Penyuluhan Agama, Jakarta: Bulan Bintang, 1979.

Arikunto, Suharsimi, Prosedur Penelitian Ilmiah, Suatu pendekatan Praktek, ED II, Cet. IX ; Jakarta : Rineka Cipta, 1993.

Aunur Rohim, Faqih, Bimbingan Konseling dalam Islam, Yogyakarta: LPPAI VII Press, 2001.

Azid, Rizem Sehat Dan Cerdas Dengan Terapi Musik, Yogyakarta: Laksana 2011.

B. Milles, Matthew, Qualitative Data Analisis, di terjemahkan oleh Tjetjep Rohen di Rohidi dengan judul Analisis Data Kualitatif, Buku sumber Metode-metode Baru, Cet, I; Jakarta UI Press, 1992. 
Mohammad Nawir, Mokh. Ulil Hidayat, Iskandar, Musik Sebagai...

Budilinggono, Bentuk dan Analisis Musik, Jakarta: Departemen Pendidikandan Kebudayaan, 1993.

Bungin, Burhan, Metodologi Penelitian Sosial, Format-Format Kualitatif dan Kuantitatif, Cet, I, Surabaya: Air Langga University, 2001.

Campbell, Don, Efek Mozarat, (Jakarta Gren Media Pustaka Utama, 2001.

DEPDIKBUD.RI. Kamus Besar Bahasa Indonesia, Edisi Kedua, Jakarta: Perum Balai Pustaka, 1995.

Djohan, Psikologi Musik, Yogyakarta: Buku Baik, 2003.

Djohan, Terapi Musik: Teori Dan Aplikasi, (Yogyakarta: Galang Press, 2006.

Dzaky, Adz, Hamdani Bakran, Konseling dan Psikoterapi Islam, Jakarta: Pustaka Fajar Baru, 1992.

Efendi, M. Pengantar Psikopedagogik Anak Berkelainan, Jakarta: Bumi Aksara, 2006.

ErfanAulia, Pembelajaran Musik Untuk Anak Tunagrahita di Bengkel Sekolah Musik SLB Negeri Semarang, Skripsi tidak diterbitkan (Semarang, Jurusan Pendidikan Seni Drama Tari dan Musik, 2015.

Erman Amti Prayitno, ,Dasar-Dasar Bimbingan dan Konseling, Jakarta: Rineka Cipta, 1999.

Gazalba, Sidi, Islam dan Kesenian; Relevansi Islam dan Seni Budaya, Jakarta: Pustaka Alhusna, 1988

Pandangan Islam Tentang Kesenian, Jakarta: Bulan Bintang, 1997.

Haakim Samuel Efek Mozarat Dan Terapi Musik Dalam Kesehatan, Fakultas Kedokteran Universitas Indonesia, http://nesion23red.multiply/com/jurnal/item6 di aksestgl 7 Agustus 2016.

Had, Sutrisno, Metodologi Research Jilid I Cet, XXIX; Yogyaklarta :Andi Yogyakarta, 1997.

J. Moleong Lexy, Metodelogi Penelitian Kualitatif ,Cet, XII; Bandung : Remaja Rosda Karya, 2000.

Arifin, M., Psikologi Dakwah (Suatu Pengantar Studi), Surabaya: AlIkhlas, 1996. 
Margono, Metode Penelitian Pendidikan, Cet, II, Jakarta :Rineka Cipta, 2000

Mubarok Ahmad, Teori dan Kasus, cet, I; Jakarta: Bina Rena Pariwara, 2000.

Muhaya Abdul, Bersufi Melalui Musik, Sebuah Pembelaan Musik Sufi Oleh Ahmad Al-Gazāli, Yogyakarta: Gama Media, 2003.

Munir Amin Samsul, Bimbingan Konseling Islam, (Jakarta Amzah, 2013 Ed. 1, Cet. 2.

Murodi, Muatan-muatan Dakwah Dalam Lagu Ebiet G. Ade (Studi Analisis Tentang Muatan, Dakwah Dalam Lagu Ebiet G. Ade), (Karya Ilmiah Mahasiswa IAIN Sunan Gunung Jati), di unduhdari Ref: http://parapemikir.com /tradisi-ilmiah-islam, diakses pada tanggal 08 Mei 2016, pukul 13.45 WITA.

Nureja Matangang, Kepala Rehsos PSBG, wawancara oleh penulis di ruang kantor, tanggal 19Agustus 2016.

Satya, Ningsi, Dewi dan Tamsil Muis, "Pengaruh Penerapan Kombinasi Musik Klasik Dan Latihan Relaksi Untuk Menurunkan Stress Pada Siswa Kelas XI IPA 2 SMA Insentif Taruna Pembangunan Surabaya", Penelitian Dan Bimbingan Konseling, Februari, 2012.

Shihab, Alwi, Islam Inklusif, Bandung: Mizan, 1999.

Somantri, Sutjihati, Psikologi Anak Luar biasa, Bandung: Refika Aditama, 2006

Sugiyono, Metode Penelitian Kombinasi (Mixed Methods), Cet, I; Bandung : Alfabet, 2011.

Walgito, Bimo, Bimbingan dan Konseling (Studi dan Karir), Yogyakarta: CV. Andi Offset, 2005.

Yakub Al Barry M. Dahlan, Kamus Ilmiah Populer, Surabaya: Penerbit Arkola, 1994. 